Makaleler Articles / Artikel 



\title{
THE TRANSFORMATION OF THE ROLE OF DEDES IN MODERN TIMES*
}

\author{
Modern Zamanlarda Dedelerin Rolünün Dönüşümü
}

\section{Die Transformation der Institution des Dedetums in der heutigen Zeit}

\author{
Ali YAMAN**
}

This article deals with the transformation of the dede institution, one

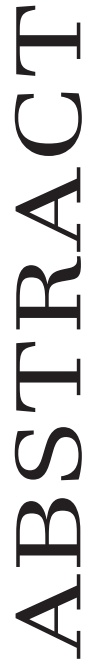
of the basic institutions of Alevism, throughout the urbanization. Dede institution played a primary role in the survival of Alevism until today. That is why it wouldn't be an exaggeration to say that this institution is of key importance for an understanding of Alevism in Anatolia. Dedes have moved away from their roles in dede-talib relations, which are based on ocaks in traditional life, and also from their traditional functions due to urbanization.

Today, cemevis and cultural centers in Turkey and the urban centers around Europe are widely run by associations and foundations. It is now clear that traditional institutions which had a significant power in the past, such as ocak institution, have been transformed. The socio-economic transformation caused by urbanization has also caused significant effects on the life of Alevis. It is necessary to compare the status of dede institution in the past with its current status in order to better understand

* This article is based on my previous works on the institution of dedelik such as Yaman (2006, 2010, 2012).

** Prof. Dr., Bolu Abant Izzet Baysal University, Division of Political History.

ORCID ID: https://orcid.org/0000-0001-5282-5686 
this situation. There are great differences between the new and the old qualifications and functions of dedes in the new social order. The functions of Dede institution have either disappeared with time, or have continued with various changes along with the new conditions and new needs of the society. The change is still continuing.

Keywords: Alevism, ocak, dede institution, transformation. 


\section{ÖZ}

Bu makale Aleviliğin temel kurumlarından olan Dedelik Kurumunun kentleşme ile yaşadığ1 dönüşümü ele almaktadır. Dedelik kurumu Aleviliğin günümüze ulaşmasında temel rol sahibidir. Öyle ki bu kurum Anadolu'da Aleviliği anlamak bakımından anahtar bir öneme sahiptir denilmesi abartılı olmayacaktır. Dedeler, kentleşmeye bağlı olarak geleneksel yaşamda ocaklara dayanan dede-talip ilişkilerinden ve işlevlerinden uzaklașmıșlardır.

Bugün Türkiye'de ve Avrupa'daki kent merkezlerindeki var olan Cemevleri ve Kültür Merkezleri büyük ölçüde dernekler ve vakıflar tarafından yönetilmektedir. Bugün artık açıktır ki eski ocak kurumu gibi geçmişte önemli güce sahip geleneksel kurumlar dönüşmüşlerdir. Kentleşmenin yarattığ1 sosyo-ekonomik dönüşüm, Alevilerin yaşamında önemli etkiler yaratmıştır. Bu durumu daha iyi anlayabilmek için Dedelik Kurumunun geçmişteki durumu ile günümüzdeki durumunu karşılaştırmak gerekmektedir. Yeni toplum düzeninde dedelerin yeni ile geçmişteki nitelikleri ve işlevleri arasında büyük farklılıklar bulunmaktadır. Dedelik kurumunun işlevleri zaman içerisinde ya tamamen ortadan yok oldu, ya da yeni koşullar ve toplumun yeni ihtiyaçları doğrultusunda değişerek yoluna devam etti. Değişim bugün hala sürmektedir.

Anahtar Kelimeler: Alevilik, Ocak, Dedelik Kurumu, Dönüşüm. 


\section{ZUSAMMENFASSUNG}

Dieser Artikel behandelt die Transformation, die die Institution des Dedetums (Dedelik), die zu den primären Institutionen des Alevitentums gehört, aufgrund der Urbanisierung durchlaufen hat. Die Institution des Dedetums spielte die Hauptrolle beim Überleben des Alevitentums bis heute. Aus diesem Grund wäre es keine Übertreibung zu sagen, dass diese Institution eine Schlüsselbedeutung beim Verstehen des Alevitentums in Anatolien einnimmt. Die Dedes haben sich aufgrund der Urbanisierung von den DedeTalib-Beziehungen, die im traditionellen Leben auf den Ocaks (Geistlichenfamilien) basieren, und ihren Funktionen entfernt.

Cem-Häuser und Kulturzentren in städtischen Zentren in der Türkei und Europa werden heute größtenteils von Vereinen und Stiftungen geleitet. Heute ist es klar, dass sich traditionelle Institutionen, die in der Vergangenheit über signifikante Macht verfügten, wie die Ocak-Institution, transformiert haben. Die sozioökonomische Transformation, verursacht durch die Urbanisierung, bewirkte erheblichen Einfluss auf das Leben der Aleviten. Um diese Situation besser verstehen zu können, muss die Situation der Institution des Dedetums in der Vergangenheit mit ihrer heutigen Situation verglichen werden. In der neuen Gesellschaftsordnung lassen sich bedeutende Unterschiede zwischen den neuen und alten Qualifikationen und Funktionen der Dedes finden. Die Funktionen der Institution des Dedetums sind mit der Zeit entweder vollständig verschwunden oder wurden unter Veränderung gemäß den neuen Bedingungen und neuen Bedürfnissen der Gesellschaft fortgeführt. Die Veränderung hält bis heute an.

Schlüsselwörter: Alevitentum, Ocak, Institution des Dedetums, Transformation. 


\section{INTRODUCTION}

Before analyzing the dede institution and its roles in Alevi society within centuries, a general assessment of Alevism should be useful. This article is based on the argument that Alevism and its institutions cannot be understood without taking considering the historical migration process of Turks from their motherland Asia to Anatolia. Both the religious and cultural context in Anatolia and Asia and their experiences in the long process of migration affected the transformation of Alevi institutions. Thus, to examine the roots of Alevism-Bektashism by only focusing on the events that gave rise to Sunni- Shi'ite split on Islam would be historically and sociologically invalid. The crucial studies on the issue, such as the works of Fuad Koprülü, F.W. Hasluck, Irene Melikoff, Sureya Faruki and Ahmet Yaşar Ocak prove my argument. In other words, I assert that to understand Alevism it is crucial to examine the religious and cultural syncretism of the belief which is the result of interaction between Turkish-Alevi society and other groups in different geographies throughout the history. Alevism in Anatolia can be defined as a type of "folk Islam" created by this syncretism. It is a "folk Islam" because it is based on oral tradition in which both the myths and beliefs of the old Turkish generation survive under the Islamic tradition.

The institution of Dede will be will also analyzed within this historical and sociological context. For centuries, the institution of Dede has been one of the basic structures in the Kizilbash Alevi society. The other key institutions of Alevism, the Alevi "ocak" is also based on Dede families. The role of Dedes in Alevi society is not only restricted to religious issues, but they also deal with educational and judicial mechanisms in society. Members of Alevi Ocak were at the top of the social hierarchy; hence their hierarchical position and spiritual authority helped them maintain social order. It is obvious that Kizilbash Alevi dedes have taken crucial role in the survival of Alevism in Anatolia. However; their traditional roles have transformed throughout history.

Before moving on to evaluations of the traditional state and its transformation, I find it useful to introduce the background of the studies on the "Dedelik" (Religious Guideship) Institution. Especially in the late 1990s, both Alevism and the "dedelik" institution began to attract more researchers' attention. Academic institutions and academicians in particular have carried out various studies. In addition to many symposiums, conferences and panels, numerous books and articles were published. 
Many foreign academicians, such as Markus Dressler, Gloria L. Clarke, Martin Sökefeld, David Shankland, Ayfer Karakaya-Stump, Robert Langer, Janina Karolewski, Hiroki Wakamatsu, Elise Massicard, Academicians or researchers from Turkey, such as Alemdar Yalçın, Mehmet Ersal, Gıyasettin Aytaş, Nilgün Çıblak Coşkun, Sabır Güler, Bülent Akın, Ahmet Taşğın, Rıza Yıldırım, Ali Selçuk, Havva Selçuk, Hayri Şanlı, Doğan Munzuroğlu, Hüseyin Çakmak, Seyfi Muhundi, Erdal Gezik, Veli Saltuk, Piri Er, Fevzi Rençber, Talip Tuğrul, Yılmaz Arı, Hasan Öğütçü, Mesut Özcan, Erdoğan Yalgin, Dilşa Deniz, Mehmet Demirtaş, Hüseyin Dedekargınoğlu, Musa Karakaş, Baki Yaşa Altınok, Yalçın Çakmak, Abbas Ulusoy, Mehmet Bayrak, Arif Kala, Hamza Aksüt, İrfan Çoban, Refik Engin, Ayhan Aydın, have also published many studies on the subject. ${ }^{1}$

While my studies in the 1994s focus more on the understanding of the traditional structure, from 2006 onwards my attention centres on the transformation of Alevism, including the "Dedelik" Institution, and its current problems. My master thesis, that started in 1996 and focused on the functions of the "Dedelik" Institution, continued with my PhD thesis entitled The Process of Change in Alevism within the Framework of the Institutions of Religious Guideship, completed in 2001. During my master's and doctoral studies, the transformation of Alevism and its institutionalization through "cemevi" reached its peak. I conducted interviews with elderly "ocakzade"s for a year in my room in the Shahkulu Dergah (Lodge). I asked them to talk about their childhood because after them, it would be no longer possible to find anyone to talk about those times. Over the years, I've come to understand how right I was. At the same time, I regret not having more conversations with people who had seen so much more of this traditional life. There are so many questions I could have asked them. However, I believe that I have brought a new approach to the subject by supporting the information that has been known until then, both in terms of literature review and fieldwork. I am very happy to see that our efforts aren't wasted as I see the references made to my studies in other researchers' studies.

Here, I would like to present the latest studies to the interested parties by mentioning some of the books on the subject of "ocak" (hearth), done in Turkey and abroad:

-Alevilik: Kavramlar ve Ocak Sistemi Çubuk Havzası Örneği, (“Alevism: Terms and Ocak/Hearth System - The Cubuk Basin Example”) (Ankara, Gazi Üniversitesi

1 For many of their works see the bibliography. 
Türk Kültürü ve Hacı Bektaş Veli Merkezi Yayını, 2016) study done by Mehmet Ersal.

-İz Brrakan Erenler ve Alevi Ocakları. ("Notable Erens and Alevi Ocaks/ Hearths") (2. printing, Ankara, 2011) study done by Veli Saltık.

-Alevi Ocakları ve Örgütlenmeleri ("Alevi Ocaks/Hearths and Their Organization”) (Ankara, Kalan Yayıncilik, 2013) study done by Erdal Gezik and Mesut Ozcan.

-Ocak und Dedelik Institutionen religiösen Spezialistentums bei den Aleviten, ("Ocaks/Hearths and Dedelik/Religious Guideship as Religious Institutions Among Alevis”) (Frankfurt: Peter Lang GmbH, 2013) study done by Robert Langer, Hüseyin Ağuiçenoğlu, Janina Karolewski and Raoul Motika.

The urbanization process after the establishment of the modern Turkish Republic and structural exclusion towards Alevis are two main dynamics that determine the deterioration of dedelik. While the urbanization process caused the breaking down of the relations between dede and talip; the favoritism, towards Sunni Islam by the government officials, the exclusion of Alevism form the public sphere, especially related to the educational and religious issues, affected the role of dedelik in society. However, in the 1990s due to the revival of the Alevi movement in Turkey and Europe, dedes regain their roles in the religious sphere. Although they do not have a strong position in the current society should be concerning their traditional role, the institution of dede still has a crucial role to understand Alevism and its transformation. This article, first, analyzes the status and the importance of dedelik; then it focuses on the transformation of the role of dedes.

As a well-known story, the foundation of the Republic of Turkey after the collapse of the Ottoman Empire and the rural depopulation transformed the traditional structure of the socio-economic life in Turkey. Compared with Sunnis, it can be argued that Alevis encountered more problems during this transformation and their adaptation to modern urban life. Since the traditional religious life was practiced only in rural areas, Alevis felt as outsiders in modern cities in both religious and cultural sense. As a result, the ocak system, which is based on the dede-talip relationship, and which has a vital role on the social structure of Alevism, gradually became alienated from its traditional tasks. Moreover, this process adversely affected the relations between the families of Alevi dedes and their talips and the other non- 
Alevi communities as well. With the rise of urbanization and adaptation to modern urban life, the traditional Alevi institutions started to lose their significance.

One of these traditional Alevi institutions is the institution of dedelik, which is represented by the spiritual leaders of Alevis who lived in closed communities since the 16th century. This institution has a crucial role to understand Alevism. The spiritual leaders of the community are named dede, baba, pir, mürşid or rehber. Dedes are recognized as the head of the social hierarchy. They are responsible for the religious affairs, and their authority (and power of sanction) over the community give them an important role in the society. That's why it wouldn't be an exaggeration to say that this institution is of key importance for understanding Alevism in Anatolia.

Alevi dedes are the members of the ocaks located in various cities of Turkey, and they are also authorized under the name of ocakzade (literally, sons of hearth). The ocakzade dedes, also called seyyid, are believed to be the descendants of the Prophet (Evlad-ı Resul). There are a series of documents proving that they have the confirmation of certain lodges and Nakibül Essraf (the chief of the descendants of the Prophet). Dedes usually visit their talip communities, perform religious ceremonies, enlighten the public and help community members to overcome the controversies among them. It has been known for a long time that there is a division of labor among the ocakzade dedes similar to the one among mürsids-pirs-rehbers. This can also be expressed with the principle of El ele el Hakk'a. This is why dedes, one of the members of ocaks, constitute a kind of domestic hierarchical order to provide discipline for its members.

The people whose names were given to ocaks, such as Ağuiçen, Sarı Saltık, Hıdır Abdal, Baba Mansur, Hubyar Sultan, Şah İbrahim Veli, were ranked based on their characteristics related to their ancestries, miracles and services. The Alevi-Bektaşi religious leaders throughout Anatolia and the Balkans can be categorized into four:

1. Independent ocakzade dedes,

2. Dedes/babas/vekils (representatives) affiliated with the Çelebis of Hac1 Bektaş,

3. Dikme dedes/babas commissioned by ocakzade dedes,

4. Halifebabas, halife and babas affiliated with the branch of dedebaba.

The Alevi community recognized dedes as the heads of the social hierarchy, but their power diminished because of the new social structure emerged after the 
foundation of the Republic of Turkey. There are a number of factors damaging the structure of dedelik such as the positive discrimination towards Sunni Islam by the official administrations, the breakdown of the relationship between dedes and talips, which stemmed from the exclusion of Alevism from public life especially from educational and religious services. Nevertheless, starting with the 1990s, the role of dedes in the society has been revitalized, especially in cemevis in Turkey and Europe. Although today dedes are far from their heydays in the past, they began to earn their old reputation in the community with respect to new social requirements. Alevis, most of whom live in cities, have more different characteristics and needs than the traditional ones living in the countryside. It is clear that there are some differences against Alevism in terms of understanding, relation and practice. Alevism can be able to continue its existence as an identity in the cities where traditional Alevi institutions but its ethnocultural dimension rather than its belief aspect becomes prominent. Compared to their traditional functions, now Dedes are much more delimited and have transformed into salaried or voluntary relief leaders serving at hundreds of downtown Cemevis of which communities come from different regions.

\section{THE TRADITIONAL ROOTS OF THE INSTITUTION OF DEDELIK}

In this section, the origins and the formation of the institution of dedelik in Anatolia are explained in light of historical events.

Although there is not sufficient evidence, it can be predicted that there is a close linkage between the constitution of dedelik and the colonization movement headed by the sheiks and dervishes succeeding their migration to Anatolia. Ocaks were called by the names of the surviving dervishes, which implies their close relationship. These dervishes lived in different parts of Anatolia, established dervish lodges, contributed to the population growth, provided sustainable economic growth and became spiritual leaders. It is important to underline that Alevi ocaks contain a spiritual identity and have survived until today through their descendants.

There is different historical evidence, which support this hypothesis. For instance, Baba İlyas, Hacı Bektaş-1 Veli, Emirci Sultan, Dede Garkın and Sarı Saltuk were some of the most powerful and active sheiks in Anatolia in the 13th century. Their power and influence can be proved by the extent of the Babailer uprising in the same century. Until now, the names of Dede Garkin and Sar1 Saltuk have survived with some Alevi ocaks. Also, in Vilayetname, it is possible to see some associations 
titled as Karadonlu Can Baba, Cemal Seyyid, Seyyid Mahmut Hayrani, Hacı Doğrul (Gözü Kızıl) and Güvenç Abdal. Moreover, it is possible to see the names of some dervishes such as Samit Abdal (Sheik Samit or Samut) and Hizır (Hidır) Abdal who were recorded in the Tales of the Ottoman Baba and in Sheik Muhyiddin Celebi's Divan in the 15th century (see Gölpinarlı 1968, 792; Ocak 1992, 102; Yaman 1989, 140).

The concept of Evlad-ı Resuldescendants of the Prophet has developed and taken its current form do to the Safavi propaganda. According to the Alevi tradition, it is a mandatory qualification to become a dede. As a result of the intense Safavi influence and activities targeting Alevis, Alevis mobilized and became more organized. Besides, the institution of dedelik became consolidated with the help of the written documents (Buyruks) that were brought by the halifes, the assistants of Shah Ismail. Embedded with Shiite motifs, Alevi Islam, spread throughout Anatolia and the Balkans. Hence, by disseminating these written documents, the halifes contributed to making Alevism have a more structured form.

Under the rule of Shah Ismail, the notion of 'ancestry' also gained importance. The fact that they used similar statements to gain a social status is why the Safavids employed the notion of sayyid to exert influence over Anatolian Alevis. Cults such as Ahl al-Bayt, Ali, the Twelve Imams and the mourning of the Kerbela incident were brought to Anatolia through the Safavi propaganda in the late 15th century and, they became the key factor in promoting the notion of 'ancestry'.

In conclusion, the institution of dedelik was born as a result of these legendary characteristics of Alevi ocak leaders such as Dede Garkin, Sar1 Saltuk, Baba Mansur, Hidir Abdal who were the descendants of the Twelve Imams. These ocak leaders contributed to the construction of legendary dede title. In addition, Alevis show respect for the descendants of those who became dede ocaks it must be taken into consideration that there are some similarities between dedes and the spiritual leaders of the ancient Turks, both in terms of context and form. Bozkurt (1996: 86) claims: "In my opinion, the institution of dede or sheikh in Alevism is a special survival from shamanism. There is a remarkable similarity between the lifestyle and the functions of the dedes and those of the shamans..."

The study of 'ancestry' in the context of dedes should first consider its meaning during the Old and Middle Ages. During this period, being a descendant of the nobility 
had its privileges. Only those who managed to prove that they are a descendant of either the Sultan or the Prophet could receive political and/or religious power.

In terms of their internal organization, every Alevi-Bektaşi community follows a particular dergab (convent) or ocak (hearth). Which dergab or ocak one is affiliated with is of primary importance. Alevi ocaks carry the names of holy religious figures that are, by tradition, assumed to be the descendants of the Prophet through the line of Ali (seyyid) such as Dede Garkın, Sar1 Saltuk and Kara Donlu Can Baba. Over time, the descendants of these holy dervishes called ocakzade institutionalized the ocaks members of these ocakzade families. Similar to the institution of dedelik, ocaks have been scarcely researched. Below they are explained only at an introductory level.

\section{WHEN DID THE ALEVI OCAKS EMERGE}

It is well known that Alevi-Bektassi groups have different kinds of beliefs associated with their customs. Dedebabas, celebis, ocakzade dedes, babas and dikme dedes all come from different origins. There are four main hypotheses for these differences:

1. The Alevi ocaks were first founded during the time of Hacı Bektaş-1 Veli.

2. The Alevi ocaks existed before the time of Hac1 Bektaş-1 Veli and were founded by the descendants of Ali.

3. The Alevi ocaks first emerged during the time of Shah Ismail.

4. The religious and political leaders of the Turkmen tribes who migrated to Anatolia later became the founders of ocakzade dede families.

The interviews I conducted with dedes also include crucial assertions related to these hypotheses. Each of these hypotheses must be examined separately in a detailed way.

\section{THE CLASSIFICATION OF OCAKS}

Alevi ocaks can be classified according to various criteria such as their functions, organizational patterns and ritual practices.

According to their functions:

1. Ocaks of the mürsid

2. Ocaks of the pir

3. Ocaks of the rehber

4. Ocaks of the dïskën (excommunicated). 
Some independent ocaks later joined çelebi ocaks; hence a distinction is also made between:

1. Dönük (convert) ocaks

2. Purut ocaks

According to their ritual practices:

1. Ocaks who use erkân

2. Ocaks who use pence

\section{THE TRADITIONAL QUALIFICATIONS OF KIZILBAŞ ALEVI DEDES}

Because the Alevi communities in Anatolia are geographically dispersed, there are often wrong assessments about them. The Alevi ocaks are numerous and diverse in all dimensions. Nonetheless, the existing literature comprises of numerous easy generalizations. For example, on the hierarchy of dedes, Hasluck (1929: 147) claims:

The priests are called Dede: above them are bishops and patriarchs. Of the latter, there are two, one of whom resides in a tekke at Khubyar, fifty-five kilometres northeast of Sivas. The patriarchs are descendants of Ali and infallible in doctrine. The religious head of the Kizilbash resides in the Dersim.

In fact, according to the traditions that survived among Alevis and the books of Buyruk, which include the basic principles of the Alevi faitha dede must have the following qualifications:

1. to be a descendant of the Prophet (ocakzade),

2. to operate as an educator and a moral guide (murebbi) for the community,

3. to be knowledgeable and exemplary in his character and manners (insan-i kami),

4. to follow the principles written in the Buyruks, and the established traditions of Alevism. ${ }^{2}$

In traditional life, every Alevi-Bektaşi community followed a particular dergah or ocak. While tekkes and zaviyes operated mostly in cities, belief centers, called ocaks, operated in rural regions. Alevis in rural regions were under the influence of dedes associated with these ocaks relatively to a greater extent. According to some sources,

2 On the issue of the qualifications and functions of dedes, see also Bumke, 1991. 
it is highly possible that there was a relationship between the Alevi ocaks and the cult of the hearth, which was common among the pre-Islamic Turks (For example, see Er, 1998: 83-91). Because the rural Alevi communities had an oral tradition, there is currently no sufficient data, and hence, more research in this area is needed.

\section{'THE CHANGE IN DEDES' QUALIFICATIONS}

In traditional rural life, dedes used to be the men of wisdom, education and moral guide. They were well-educated people knowing the Ottoman script as well. They had broad knowledge about various issues; they had written sources and carried the oral culture to the younger generations. Overall, these characteristics gave them a traditional authority in society. In the past, dedes had a leading and active role in ensuring the justice in society by using their traditional and religious authority, which came from their ancestry. In this way, their authority in society continued for centuries. However, due to the rise of the modern education system, their privileged status has been weakened in time. Today, they are deprived of their traditional roles, and as such, their juridical and exemplary roles disappeared.

There are many different aspects of the change that ocaks/hearths experienced after urbanization. The socio-economic transformation brought about by urbanization has caused the emergence of four different Ocakzade dede/religious guide typology today:

1. As a new phenomenon, dedes who give religious services either on salary or voluntary basis in cemevis, associations and foundations where Alevism is experienced and applied in cities,

2. Dedes, members of the traditional Ocakzade families, who are not in charge of certain cemevi, association or foundation but maintain their religious services among Alevi society both in cities and in Anatolia,

3. Dedes who don't maintain religious services belonging to the traditional dedelik/religious guideship but who have information and observations obtained from their fathers or relatives and/or informed by written sources,

4. Another group can be described as "members of dede families who aren't knowledgeable as they don't serve cem" (Yaman, 2012: 23-24).

And there are also many changes that the institution of dedelik is facing at present day. Many young descendants of dedes do not aspire to become a dede due to the 
existing social conditions. Only a few of them are willing to provide this religious service, even though cemevis are institutionalized in cities. Secondly, at the present day, dedes do not work voluntarily, but are paid and are in charge of jobs allocated by the heads of Alevi associations. Thirdly, in the old days, the dede-talip relations were based on Alevi ocaks and used to take the ancestry relations as the basic parameters. It was compulsory for dedes to be an ocakzade, in other words, to be an Evladi-Resul or to come from an ocakzade family, which has an ancestry of Alevi-Bektassi path exalter who had achieved to become a mürsid by means of service or prophecy. Nowadays, these qualities do not seem to be enough. The education level and the oratory skills are also necessary to achieve the dede position in the new social order.

Finally, following the principles written in the Buyruks containing the principals of the Alevi faith (known as Menakıb-1 Imam Cafer, Menakıb-1 Şeyh Safi), as well as the established traditions of Alevism was another important qualification. These principles in the Alevi tradition have been transferred from generation to generation for centuries as such: 'The "path" is the most exalted of all', 'Four Doors Forty Levels', 'Control one's hands, tongue, and loins'. These written and/or oral rules that dedes had to obey have disappeared, because the books, which determined the principles of the 'path' and which produced solutions for problems pertaining to rural life hundreds of years ago, haven't been updated. Hence the traditional Alevi institutions have disappeared, and with urbanization, the role of Alevi dedes and their position in the social hierarchy have changed.

\section{THE CHANGE IN DEDES' FUNCTIONS}

Every social institution gains its importance through its professional functions and the structures that lose their functions in social life are condemned to disappear. Thus, it would be beneficial to compare dedes' functions in the past (see Yaman, 2004: 161-171) and those in the present day in order to understand the transformation in ocaks.

Today the function of 'guiding the society as spiritual leaders and being exemplary with their behaviors and lifestyles' for ocakzades is not as effective as in the past. Notable and esteemed dedes still exist inside or outside of the Alevi institutions (associations/foundations/cemevis), but it is not possible to say that dede-talip relationships are sustainable. The development of modern education and communication means resulted in dedes' function (of being a social and religious 
guide in society) to disappear. Hence, dedes' social influence and traditional authority have been diminished in time.

Unlike those in rural areas, the dedes who serve voluntarily in cemevis in cities address to a 'hybrid' society comprised of urbanized disciples who belong to various ocaks. For instance, a dede who carries out a cem ritual may be from the Kureyşan ocak, but disciples may belong to various ocaks, and there can even be sometimes non-Alevi people in the audience. Hence, the number of dedes who address only to disciples of their ocak (i.e. who have the same ancestry) has gradually decreased.

It is evident that the traditional function of 'being the enlightener and the educator' in a community does not work anymore. This function has been replaced by the newly established educational institutions, facilities and written or visual communication channels that reach the farthest regions of Turkey. Faith centers (in the form of associations/foundations/cemevis) have also started to subrogate ocaks, zakirs, and saz/semah instructors. The administrators of these institutions are able to take up the role of enlightening society alongside dedes. Besides, the widespread educational institutions and communication channels pursue this function. Since ocaks lost their functions after urbanization, cemevis emerged since the 1990s in cities, but the lack of knowledge in faith issues in these places still raised the necessity for dedes.

The traditional function of 'securing social unity and solidarity' has also vanished. In fact, this function was related to the guiding role of dedes in society. Their spiritual and social guidance is used to allow them to secure social unity and solidarity. As a parallel to their weakening in power and social influence, this function has lost its force also in cities. Instead, faith centers (in the form of associations/foundations/ cemevis) have started to take up this role.

Traditionally, dedes have carried out the function of 'leading social/spiritual rituals and rites (such as the cem ritual, funeral and marriage ceremonies)'. These rituals and rites have been interrupted in most places since the 1990s, and a big vacuum emerged in the absence of a divine authority in the urbanized society. Many Alevis in cities who did not have access to cemevis were unable to find Alevi preachers or dedes to carry out their funeral and wedding ceremonies. Thanks cemevis, which started to be established in the 1990s, they can now have access to big cities' funeral services. Wedding ceremonies were not only carried out by dedes, but also by older Alevis 
who did not necessarily have a dede ancestry. The demand for dedes to conduct these ceremonies increased due to the opening of cemevis.

The traditional function of 'securing justice and punishing criminals through the institution of düskeünlük' has also mostly vanished except for some rare cases. Alevis living in rural areas used to secure justice through a kind of social discipline, namely the institution of düskünlük, which was facilitated by ocaks' religious power. Also called 'the people's court', this was a domestic legal order ensured by dedes asking the people's opinion and holly worshiping the ocakzade community. The transformation of urbanized Alevi communities in the current socio-economic structure has resulted in destroying this old traditional justice mechanism too. The institution of dïskeülük is still carried out in some communities, which try to keep their traditional structure and their dede-disciple relations alive. However, these are very few in number. Overall, the change in the institution of dïskënlük is important to understand the great transformation in Alevism.

The function of 'keeping the faith and the traditions alive and transferring them to the next generations' has survived in villages for centuries mostly with the help of ocakzade dede families. In addition to coming from a dede ancestry, dede families have had a privileged status in transferring the Alevi faith and traditions to the next generations. Ocaks were deprived of these functions after the great transformation that came with urbanization. After the 1990s, new cemevis started to be built during the process of 'returning back to the Alevi identity', and this process made dedes necessary for the ritual faith services. Traditionally, it was the ocakzade dede families who had the adequate knowledge to carry out this tradition, but nowadays, dedes carry it out only partially.

The traditional function of 'being the responsible person for those people who are in financial or spiritual need and who are sick' has also diminished considerably. Disciples used to give financial support to dedes-known as hakkullah, çuraklike, and dedes used to use some of this support for the society and even give some of it to the disciples who were in financial need. They also supported the disciples spiritually with the help of their role of being a religious leader in their society. Moreover, dede families were known to be the health care providers by using a various solutions including traditional folk remedies. For example, those people who had minor ailments went to the dedes of Sarısaltuk ocak in Tunceli, Hozat. Because of the development of modern medicine, the function of dedes also weakened. 
THE CHANGE IN THE RELATIONSHIP BETWEEN DEDES AND THE CEM RITUAL

The change in the institution of dedelik has also influenced the cem ritual. After cemevis were established in cities, this religious service, which was previously carried out by ocaks, started to be controlled under a hybrid authority. Like ocaks, the cem ritual has also been affected by urbanization. Erdemir (2005: 945) emphasizes that there is an ongoing debate over this newly emerging form of the cem ritual: while some assert that it is a lost rural tradition, others argue that there is an effort to keep it alive in modern urban life. It can also be said that cem rituals are becoming urbanized by following different paths compared with the traditional ones. Below I explain the ways how cem rituals have changed.

First, the purpose and the traditional functions of the cem ritual have changed. The functions of faith, education and justice are not as prevalent as in the past. Today some cem rituals are practiced in big sport halls as a representation of the Alevi identity and broadcasted on TV channels every week.

Second, there has been a major change in the status of dedes. Cem rituals are carried out weekly every Thursday night and are called the 'Friday night'. In urban life these cems are led by incumbent dedes who work voluntarily or who are paid. These dedes are determined by the directors of Alevi associations or foundations. Dedes who do not work in cemevis can carry out cems only under exceptional conditions, for instance when the dede of a cemevi gets sick, or quits. Today almost all cems carried out in cemevis are conducted in this way. Other cem rituals are 'etiquette and/or Hizir cems' trying to keep the dede-disciple relationship based on ancestry related to an ocak. These are carried out by disciples together with dedes of ocaks a few times a year. If the dede of an ocak and his disciples wish to carry out the cem ritual not in houses but in a cemevi, they have to get permission from the cemevi administration. As cems are regularly carried out in these places, it is not easy to have permission for Thursday nights. Hence, it is possible to argue that cem rituals are not only in control of dedes of ocak (and cemevis' dedes), but mostly under the control of the cemevi administration. It can be said that ocaks do not have an influence on disciples anymore and dedes gain their power not through their ocaks but through other ways.

Third, the functions of the services in cem, namely the twelve services and the way they are carried out, have changed. Some services are now dysfunctional; others 
have completely changed (for instance, now mail, telephone, media, or TV can be used instead of peyikesi).

Fourth, the traditional places where cems are carried out have changed. Cems used to be carried out usually in mobile places that is to say in big rooms or cemevis. Now they are carried out mostly in some cemevis, dervish lodges or associations.

Fifth, there is also a change in the days when cems are practiced. In the past, cems used to be carried out by dedes on Friday nights, now they are carried out in weekends or in days depending on social demands. For instance, Şahkulu Sultan Dervish Lodge, which is one of the most notable dervish lodges in Istanbul, and which now functions also as a cemevi, holds cem rituals on Fridays, which is the day when most people come in.

Sixth, the physical environment of the place where cems are carried has changed. Service holders now wear folkloric clothing instead of casual and dedes who lead the cem and zakirs who play saz, wear ties. It is also seen that the pictures of famous political figures are hung on walls along with traditional religious leaders such as Imam Ali and Hacı Bektaş.

Seventh, the tools that are used during cems have changed. Traditional tools like ocak, post, baton (tarik) and candles disappeared. Instead, new tools such as electric lamps instead of candles, lecterns on which dedes put texts of idioms and prayers, microphones, video recordings and professional zakirs became part of the contemporary cems.

Eighth, the purpose and the intention of participants in cems have changed. In the past, the purpose was to perform the ritual. Nowadays people attend cems for different purposes. Few Alevis attend them regularly since they are members or incumbents of cemevis/associations; some attend because they are the service holder; some attend to see them for the first time; few attend for research purposes; and some Sunnis attend to see what is happening and test what they previously heard. Rituals range from worship to teaching.

Finally, the impact of cem rituals on the participants, including the dedes has changed. In the past, Alevis used to understand the language used in cems as well as the mystic and spiritual environment in traditional life much better. Now idioms, expressions and information mentioned in prayers cannot be fully understood by 
the contemporary people. Overall, the change in the institution of dedelik, which was shaped according to the conditions of centuries ago, and which failed to be updated for various reasons, and the change in the urbanized population's ability to understand the cem rituals and to apply them in their life daily are the indicators of the great transformation in Alevism.

\section{THE CHANGE FROM OCAKS TO NEW FAITH ORGANIZATIONS}

It is remarkable that the oral tradition of Alevism has transformed into a written style together with urbanization. With the increase of the number of cemevis, many people who work in other jobs started to be interested in the institution of dedelik. Similarly, some institutions in Turkey and Germany need further institutionalization, which would be comprised of ocak members. One example for this is the Faith Council, which was established by twelve dedes and anas in AABF (Alevi Federations) in Germany and which is a crucial entity related to the faith services. Another one is the Alevi Islam Religious Services Directorate founded by the CEM Foundation in Turkey. Parallel to the needs of urbanized Alevis, these institutions try to prepare various educational programs for ocakzade dedes. To this end, the CEM foundation opened a dede course, which is still active. Also, the AABF Faith Council annually carries out dede-ana seminars in Germany (Kaya, 2012: 9).

\section{CONCLUSION}

As I mentioned before, the institution of Dede is the most important of all the institutions integral to the social and religious organization of the Anatolian Alevis. Although much weakened due to the socio-economic transformation experienced in Anatolia towards the end of the nineteenth century, and particularly due to accelerated migration from the rural to the urban areas after the foundation of the Turkish Republic, it played a primary role in the survival of Alevism until today.

In conclusion, the roles of Dedes have changed a lot since the beginning of urbanization. Dedes have experienced great changes in terms of qualities and functions they have had. Urbanized Alevism symbolizes an important transitional period with its all institutions. The adaptation of Alevism into city life, which has taken form up to traditional life and continued its existence in this way, is a really difficult issue. Our duty is to observe and to analyze this transformation. 


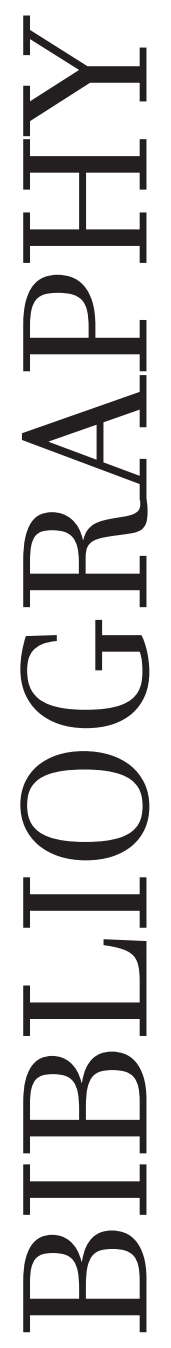

AKSÜT, Ali Kemali (1932). Eræżincan Taribi, Coğrafi, İstimai Etnografi, İdari, İbsai Tetkikat Tecrübesi. Istanbul: Resimli Ay Matbaası.

ATALAY, Besim (1991). Bektasilike ve Edebiyat, $2^{\text {nd }}$ edition. Istanbul: Ant Yayınlar1. AYTEKIN, Sefer (1958). Buyruk. Ankara: Emek Basım-Yayımevi.

BARKAN, Ömer Lütfi (1942). "İstila Devirlerinin Kolonizatör Türk Dervişleri ve Zaviyeler". Vakefflar Dergisi. 1942/2. 279-365.

BIRGE, John Kingsley (1937). The Bektashi Order of Dervishes. London: Luzac $\&$ Co.

BRUINESSEN, Martin van (2009). "Sufism, 'Popular' Islam and the Encounter with Modernity". In: Islam and Modernity: Key Issues and Debates, edited by M. K. Masud, A. Salvatore, M. van Bruinessen. Edinburgh: Edinburgh University Press. 125-157.

BUMKE, Peter J. (1991). “Dersimde Kızılbaş Kürtler”. Berhem 1991. 11-12, 1821.

CLARKE, Gloria L. (1999). The World of the Alevis: Issues of Culture and Identity. New York and Istanbul: AVC Publications.

DRESSLER, Markus (2006). "The Modern Dede Changing Parameters for Religious Authority in Contemporary Turkish Alevism". In Speaking For Islam Religious Authorities in Muslim Societies, edited by G. Kramer and S. Schmidtke. Leiden: Brill. 269-294.

ELLINGTON, George (2004). "Urbanization and the Alevi Religious Revival in the Republic of Turkey". In Archaeology, Anthropology and Heritage in the Balkans and Anatolia: The Life and Times of F. W. Hasluck, 1878-1920, edited by David Shankland. Istanbul: The ISIS Press. 369-401.

ERDEMIR, Aykan (2005). “Tradition and Modernity: Alevis' Ambiguous Terms and Turkey's Ambivalent Subjects". Middle Eastern Studies. 2005/41 (6). 937951.

ERSAL, Mehmet (2016). Alevilik: Kavramlar ve Ocake Sistemi Çubuk. Havzası Örneği. Ankara: Gazi Üniversitesi Türk Kültürü ve Hacı Bektaş Veli Merkezi Yayını.

GEZIK, Erdal and Mesut Özcan (2013). Alevi Ocaklar ve Örgütlenmeleri. Ankara: Kalan Yayinclik.

GÖLPINARLI, Abdülbaki (1968). “Kızılbaş”. In İslam Ansiklopedisi. Vol.6, edited by İstanbul Üniversitesi Edebiyat Fakültesi. Istanbul: Milli Eğitim Basımevi. 789795.

HASLUCK, F.W. (1929). "Christianity and Islam Under the Sultans". edited by Margaret M. Hasluck. Oxford: Clarendon Press.

KAPLAN, İsmail (2006). "AABF'de Dedeler Eğitimi başliyor". Alevilerin Sesi. 2006/99 (11). 26-27.

KAROLEWSKI, Janina (2020). "The Materiality of Alevi Written Heritage: Beautiful Objects, Valuable Manuscripts, and Ordinary Books". Aesthetic and Performative Dimensions of Alevi Cultural Heritage, Ed. By M. Greve, U. Özdemir, R. Motika, Baden-Baden: Ergon Verlag. 175-211.

KAYA, Müslüm (2012). "AABF İnanç Kurulu Toplantısı." Alevilerin Sesi. 2012/162 (7). 9. 
KEHL-Bodrogi, Krisztina (1996). “Tarih Mitosu ve Kollektif Kimlik”. Birikim. 1996/88. 52-63.

KILIÇ, Rüya (1994). Hilafet Mücadelelerinin İslam Taribinde Ve Osmanl Imparatorluğu'nda Toplumsal Yapıdaki İzdüsümü: Seyyid ve Şerifler. Ankara: Hacettepe University Unpublished MA Thesis.

MOTIKA, Raoul, R. Langer, H. Ağuiçenoğlu, J. Karolewski (2013). -Ocak und Dedelik Institutionen religiösen Spezialistentums bei den Aleviten. Frankfurt: Peter Lang GmbH.

OCAK, Ahmet Yaşar (1996). Babailer İsyam Alevîliğin Taribsel Altyapısı Yahut Anadolu'da İslâm-Türk Heterodoksisinin Teşekkeïlï, ${ }^{\text {nd }}$ edition. Istanbul: Dergâh Yayınları.

OCAK, Ahmet Yaşar (1992). Osmanl Imparatorluğu'nda Marjinal Sufilik: Kalenderiler. Ankara: TTK Publications.

POPOVIC, Alexandre; Gilles Veinstein (1995). Bektachiyya: Etudes sur l'ordre mystique des Bektachis et les groupes relevant de Hadji Bektach. Istanbul: The ISIS Press.

SAKAOĞLU, Necdet (1989). "Seyyid Garip Musa Ocağı". Tarib ve Toplum. 1989/61. 22-29.

SALTIK, Veli (2011). $\dot{I}_{z}$ Brrakan Erenler ve Alevi Ocaklar, $2^{\text {nd }}$ edition. Ankara: Kuloğlu Matbaa.

SHANKLAND, David (1999). “Günümüz Türkiye'si Alevîlerinde 'Dede' ve 'Talip' Arasındaki Değişen Bağ.” In Taribî ve Külttürel Boyutlaryla Türkiye'de Alevîler Bektaşîler ve Nusayrîler, edited by Irene Melikoff, et. al. Istanbul: Ensar Neşriyat. 319-327.

SHANKLAND, David (2013). “The Alevis in Europe: Changing Dede/Talip Relations”. In Ocak und Dedelik Institutionen religiösen Spezialistentums bei den Aleviten. edited by Robert Langer et. al. Frankfurt am Main: Peter Lang. 225-239.

SÖKEFELD, Martin (2002). "Alevi Dedes in the German Diaspora: The transformation of a Religious Institution”. Zeitschrift für Ethnologie. 2002/127. 163-186.

SÖKEFELD, Martin (Hg.) (2008). Aleviten in Deutschland, Identitatsprozesse einer Religionsgemeinschaft in der Diaspora. Bielefeld: Transcript Verlag.

STOKES, Martin (1999). "Ritüel, Kimlik ve Devlet: Bir Alevi (Şii) Cem Töreni”. In Ortadoğu'da Milliyetçilik, Ažnlkklar ve Diasporalar, edited by K. E. Schulze et. al. İstanbul: Sarmal Yayınevi.

YALMAN, Nur (1969). "Islamic reform and the mystic tradition in eastern Turkey". Archives Europeennes Sociologie. 1969/10 (1). 41-60.

YAMAN, Ali (2004). Alevilikte Dedelik, ve Ocaklar. Istanbul: Karaca Ahmet Sultan Derneği Yayınları. YAMAN, Ali (2006). Kıəllbas Alevi Ocakları. Ankara: Elips Yayınları.

YAMAN, Ali and Aykan Erdemir (2006). Alevism-Bektashism: A Brief Introduction. London: England Alevi Cultural Centre and Cemevi Publications.

YAMAN, Ali (2010). "Ritual Transfer within the Anatolian Alevis: A Comparative Approach to the Cem-Ritual". In Ritual Dynamics and the Science of Ritual, Vol. 5, edited by A. Michels (General Editor), G. Dharampal-Frick, R. Langer and N. H. Petersen. Wiesbaden: Harrassowitz Verlag. 269276.

YAMAN, Ali (2012). “Geçmişten Günümüze Alevi Ocaklarında Değişime Dair Sosyo-Antropolojik Gözlemler”. Türk Kültürü ve Hacr Bektas Veli Arasttrma Dergisi. 2012/63. 17-38.

YAMAN, Mehmet (1995). Alevilik: Innanç Edeb Erkân, $4^{\text {th }}$ edition. Istanbul: Ufuk Matbaas1. 
Ali YAMAN

24 Forschungszeitschrift über das Alevitentum und das Bektaschitentum / 2020 / 22 